\title{
ANALISIS DAN DESAIN SISTEM PENERIMAAN KARYAWAN BARU PADA PT. SURYA TOTO INDONESIA
}

\author{
Rohmat Taufiq ${ }^{1}$, Nida Maelani ${ }^{2}$ dan Liesnaningsih ${ }^{3}$ \\ Program Studi Teknik Informatika \\ Fakultas Teknik Universitas Muhammadiyah Tangerang \\ E-mail: ${ }^{1}$ rohmat.taufig@umt.ac.id; ${ }^{2}$ maelanida22@gmail.com; ${ }^{3}$ liesnaningsih@gmail.com;
}

\begin{abstract}
ABSTRAK
Penerimaan Karyawan baru dalam suatu perusahaan merupakan suatu hal yang sangat penting karena menentukan kualitas perusahaan tersebut, Dengan semakin berkembangnya teknologi dan ilmu pengetahuan, semakin berkembang pula proses pendidikan di Indonesia ini. Begitu pula kualitas tenaga kerja semakin bertambah baik yang dari dalam negeri maupun yang dari luar negeri dan jumlahnya semakin meningkat dengan pesat. Menyebabkan banyak perusahaan atau instansi-instansi sulit memilih pegawai karyawan/karyawati yang sesuai dengan kebutuhan dan ahli pada bidangnya masing-masing. Metode penelitian yang digunakan ada dua tipe yaitu metode penarian data (wawancara, observasi dan studi literature) sedangkan metode analisis dan desain yaitu dengan cara analisis, perencanaan dan desain dengan menggunakan UML. Kesimpulan dari penelitian ini adalah sebuah analisis dan desain yang nantinya bisa digunakan untuk mempermudah proses pengembangan sistem inforasi berbasis web di PT. Surya Toto Indonesia.
\end{abstract}

Kata Kunci: Analisis Sistem, Rancangan Sistem, Sistem Informasi Penerimaan Karyawan Baru.

\section{ABSTRACT}

Acceptance of new employees in a company is very important because it determines the quality of the company, with the development of technology and science, the growing education process in Indonesia. Similarly, the quality of manpower is increasing both from domestic and overseas and the number is increasing rapidly. Causing many companies or agencies to be difficult to choose employees/workers who meet the needs and experts in their respective fields. The methods of study used are two types of data Penarian methods (interviews, observations and literature studies) while the method of analysis and design is by means of analysis, planning and design by using UML. The conclusion of this research is an analysis and design that can be used to facilitate the process of development of web-based information system at PT. Surya Toto Indonesia.

Keywords: System analysis, System design, new employee acceptance information System.

\section{I.PENDAHULUAN}

Karyawan atau sumber daya manusia (SDM) merupakan aset yang sangat penting dan unik dalam sebuah perusahaan. Diantara aset-aset lain seperti modal, bangunan, mesin, peralatan kantor, persediaan barang, dan lainnya hanya karyawanlah yang dapat bernapas, berpikir, merasa, dan berperilaku.
Keunikan ini jika memiliki kualitas yang baik dan dilibatkan dalam aktivitas usaha akan memberikan sumbangan yang besar bagi kemajuan perusahaan..

Seiring dengan perkembangan zaman, tuntutan atas kulitas karyawan di perusahaan semakin tinggi tersebut dapat bertahan dan bergerak maju di tengah 
persaingan global. Perusahaan semakin selektif dalam memilih karyawan. Pada umunya perusahaan tidak memiliki cukup waktu untuk melakukan seleksi langsung atas setiap calon karyawannya, sehingga perusahaan lebih memilih untuk menunjuk pihak lain yang melakukan penyebaran informasi dan sistem seleksi yang kemudian akan menimbulkan biaya cost. Biaya tersebut tentunya menambah beban pada perusahaan dalam hal anggaran. Namun, seiring perkembangan sistem penyaluran informasi dengan menggunakan teknologi, perusahaan dapat mengurangu pengeluaran biaya anggaran untuk suatu proses perekrutan karyawan baru. Perusahaan dapat memanfaatkan teknologi informasi khususnya penyebaran informasi melalui internet dan media komunikasi seperti handphone dalam tahap perekrutan karyawan baru, sehingga perusahaan lebih mudah melakukan penyebaran informasi kepada calon pelamar.

PT. Surya Toto Indonesia dalah perusahaan yang berdiri pada tanggal 11 Juli 1997 di Jakarta, Yang bergerak dibidang sanitary dan fitting, tentu saja PT. Surya Toto Indonesia membutuhkan manusia untuk mengelola sistem tersebut. Sumber Daya manusia merupakan faktor yang sangat penting dalam perusahaan. Sumber Daya Manusia (SDM) adalah bagian dari sistem yang terintegrasi dengan baik, Dalam hal ini sistem rekrutmen atau penerimaan karyawan baru pada PT. Surya Toto belum adanya aplikasi khusus, masih menggunakan sistem Microsoft Office, membutuhkan sistem atau aplikasi pengolah data untuk menentukan calon karyawan baru secara efektif.

\section{LANDASAN TEORI}

\section{a. Pengertian Analisis}

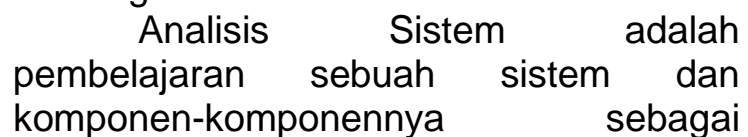
prasyarat sistem desain sistem, spesifikasi sebuah sistem yang baru dan diperbaiki. Berpindah dari definisi klasik analisis sistem ini ke sesuatu sedikit lebih kontemporer, analisis sistem adalah sebuah istilah yang secara kolektif mendeskripsikan langkah-langkah awal pengembangan sistem. Jeffery (2004).
Sedangkan menurut Yogiyanto (2005) Analisis Sistem (systems analysis) dapat didefinisikan segabagai penguraian dari suatu sistem informasi yang utuh ke dalam bagian mengevaluasi permasalahanpermasalahan, kesempatan-kesempatan, hambatan-hambatan yang terjadi dan kebutuhan-kebutuhan yang diharapkan sehingga dapat diusulkan perbaikanperbaikannya.

b. Pengertian Sistem Informasi

Sistem informasi adalah kumpulan dari sub-sub sistem yang saling terintegrasi dan berkolaborasi untuk menyelesaikan masalah tertentu dengan cara mengolah data dengan alat yang namanya komputer sehingga memiliki nilai tambah dan bermanfaat bagi pengguna. Taufiq (2013). Adapun komponen-komponen sistem informasi berbasis computer menurut O'Brien (2005) tediri dari Manusia, Hardware, Software, Data dan Jaringa.

c. Peneriman Karyawan Baru

Menurut Qodri Z (2014) Rekrutmen merupakan awal dari segala kebutuhan tenaga kerja. Tujuannya, mendapatkan hasil rekrutmen yang ideal. Ideal yang dimaksud disini adalah dapat memenuhi kebutuhan divisi kerja, baik secara kualitas tenaga kerja maupun imbalan.

d. Pengertian UML

Menurut Nugroho (2010), UML (Unified Modeling Language) adalah 'bahasa' pemodelan untuk sistem atau perangkat lunak yang berparadigma 'berorientasi objek". Pemodelan (modeling) sesungguhnya digunakan untuk penyederhanaan permasalahanpermasalahan yang kompleks sedemikian rupa sehingga lebih mudah dipelajari dan dipahami.

\section{METODE PENELITIAN}

\section{Metode Pengumpulan Data}

Metode - metode yang digunakan untuk mendapatkan informasi dan data - data yang diperlukan adalah sebagai berikut:

a. Metode Interview atau wawancara Metode wawancara yaitu pengumpulan data dengan jalan tanya jawab lisan secara sepihak yang dikerjakan secara sistematis dan berlandaskan pada tujuan penelitian.

b. Metode Kepustakaan

Yaitu dengan mengumpulkan berbagai sumber - sumber referensi baik berupa 
buku, artikel dan sumber - sumber lainya sebagai acuan analisis.

c. Metode Observasi

Disamping wawancara, penelitian ini juga melakukan metode observasi. Observasi adalah pengamatan dan pencatatan secara sistimatik terhadap unsur-unsur yang tampak dalam suatu gejala atau gejala-gejala dalam objek penelitian.

d. Metode Kearsipan

Yaitu menggunakan arsip-arsip yang ada di PT. Surya Toto Indonesi, Tbk Data-data ini meliputi:

1. Profil, struktur organisasi, visi, dan misi PT. Surya Toto Indonesi, Tbk.

2. Data penerimaan karyawan baru.

\section{Metode Analisa dan Desain}

Langkah yang dilakukan dalam menganalisis dan medesain yaitu melakukan analisis dengan tepat, melakukan perencanaan dan yang terakhir yaitu membuat desain. Desain yang dibuat dibagi dua yang pertama desain fisik yang digambarkan dengan Unified Modeling Language (UML) dan yang kedua Desain Fisik yaitu tampilan-tampilan yang diusulkan.

\section{ANALISA DAN PEMBAHASAN \\ 1. Sistem yang berjalan.}

Dari hasil wawancara dan observasi yang telah di lakukan di PT. Surya toto, sesuai pembahasan yang di ambil tentang Sistem penerimaan karyawan, adapun kesimpulan yang dapat diambil dari sistem yang sedang berjalan di PT. Surya toto yaitu sistem yang digunakan selama ini masih manual dalam hal waktu, penyimpanan file yang kurang terjamin keamanannya dan kurang efisien, dikarenakan sistem penerimaan karyawan belum maksimal. Pada sistem yang sedang berjalan di PT. Surya toto pengolahan data belum terkomputerisasi Penyimpanan karyawan baru yang masih dalam bentuk kumpulan berkas-berkas sehingga datadata karyawan bisa hilang atau rusak dan terjadi redudansi data.

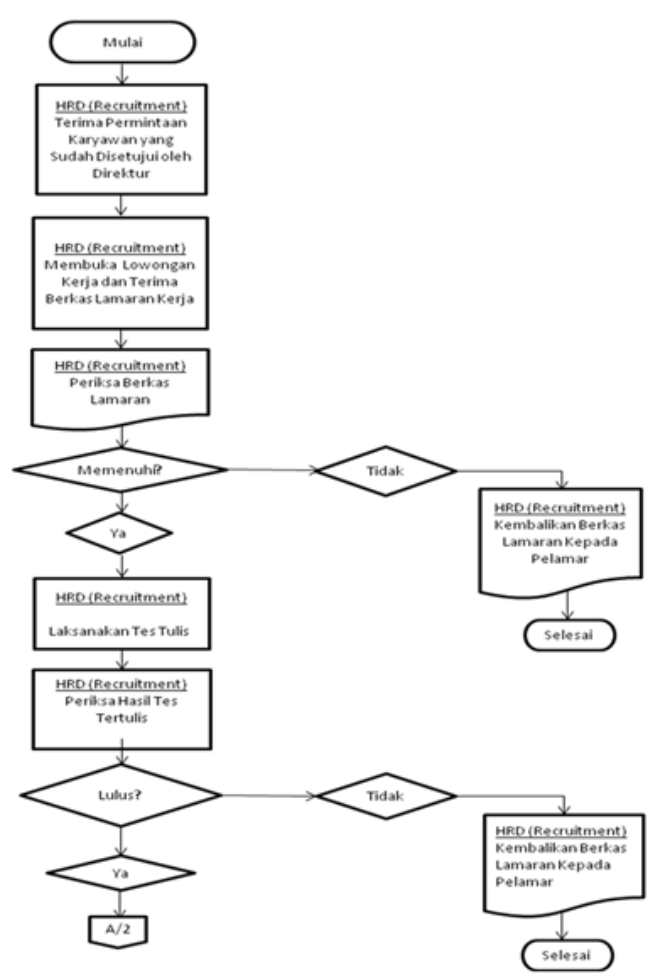

Gambar 1.a. Prosedur yang berjalan

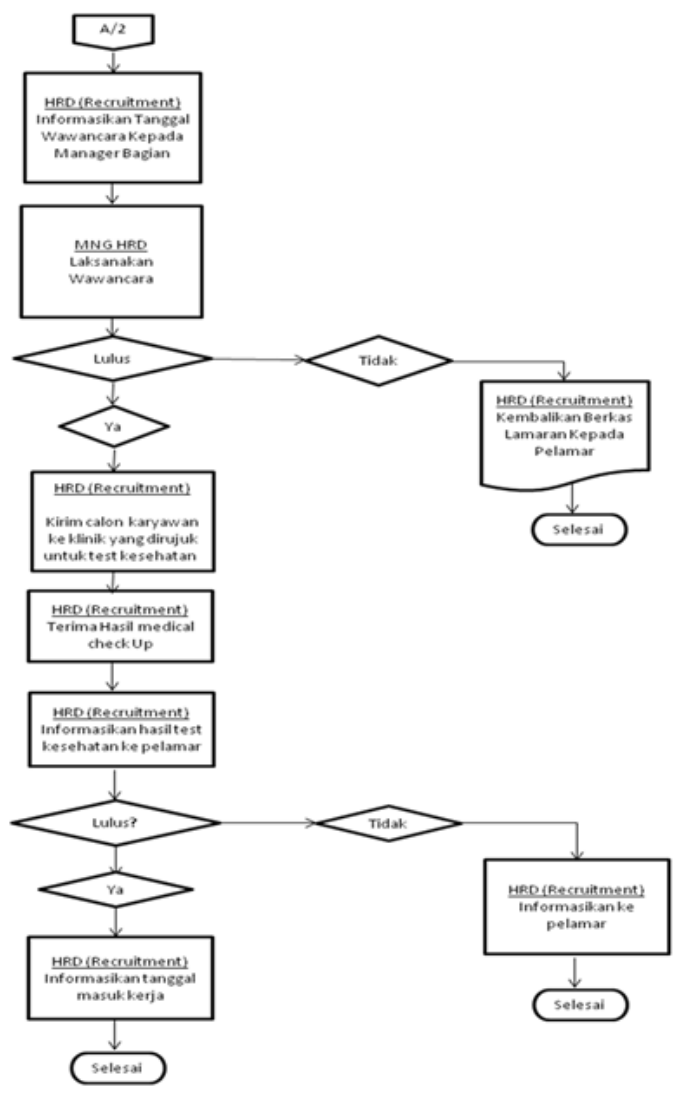

Gambar 1.b. Prosedur yang berjalan 


\section{Perancangan Sistem}

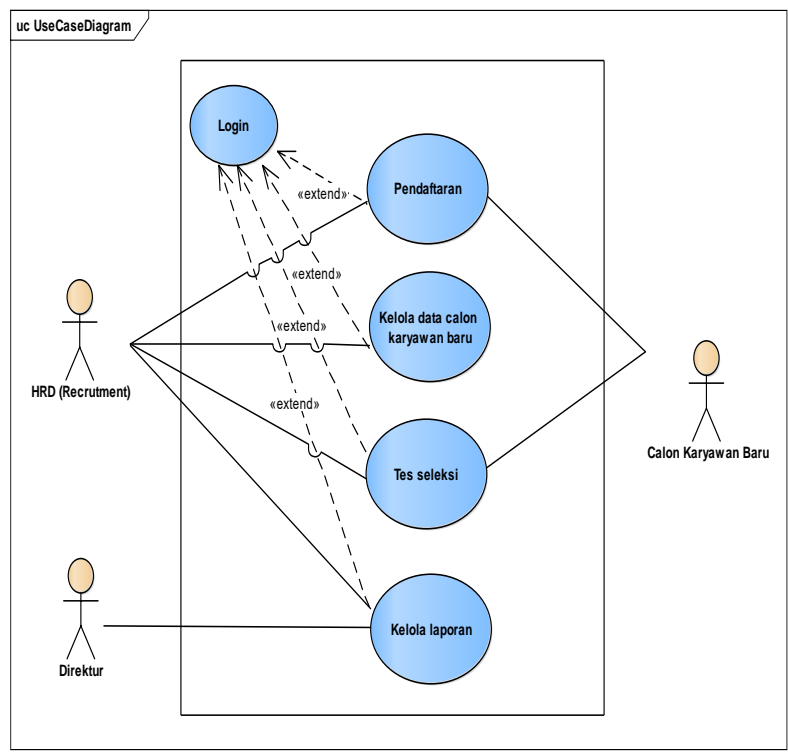

Gambar 2. Usecase Diagram Usulan

Pada Gambar 2. Usecase Diagram Sistem yang diusulkan, ada beberapa aktor yang terlibat dalam sistem, diantaranya :

Tabel 1. Penjelasan aktor Usecase Diagram

\begin{tabular}{|l|l|l|}
\hline No & Aktor & Penjelasan \\
\hline & & $\begin{array}{l}\text { HRD yaitu orang } \\
\text { yang melakukan } \\
\text { pengololahan data, } \\
\text { kelola data calon } \\
\text { karyawan baru dan } \\
\text { kelola tes seleksi, } \\
\text { kelola laporan. }\end{array}$ \\
\hline 2 & $\begin{array}{l}\text { HRD } \\
\text { (Recrutment }\end{array}$ \\
\hline & irektur & $\begin{array}{l}\text { Direktur. Menerima } \\
\text { laporan HRD. Untuk } \\
\text { review laporan yang } \\
\text { selanjutnya untuk } \\
\text { diarsipkan oleh SDM } \\
\text { div. }\end{array}$ \\
\hline 3 & $\begin{array}{l}\text { Calon Karyawan } \\
\text { Baru yaitu orang yang } \\
\text { melakukan } \\
\text { pendaftaran dan tes } \\
\text { Seleksi }\end{array}$ \\
\hline
\end{tabular}

Pada Gambar dibawah ini yaitu Statechart Diagram dan Activity Diagram yang digunakan untuk menggambarkan proses alur sistem yang di usulkan untuk PT. Surya Toto Indonesia Tbk, Diagram ini mengandung aktifitas dari masing-masing usecase pada Usecase Diagram yang diusulkan. Gambar Statechart Diagram dan Activity Diagram.

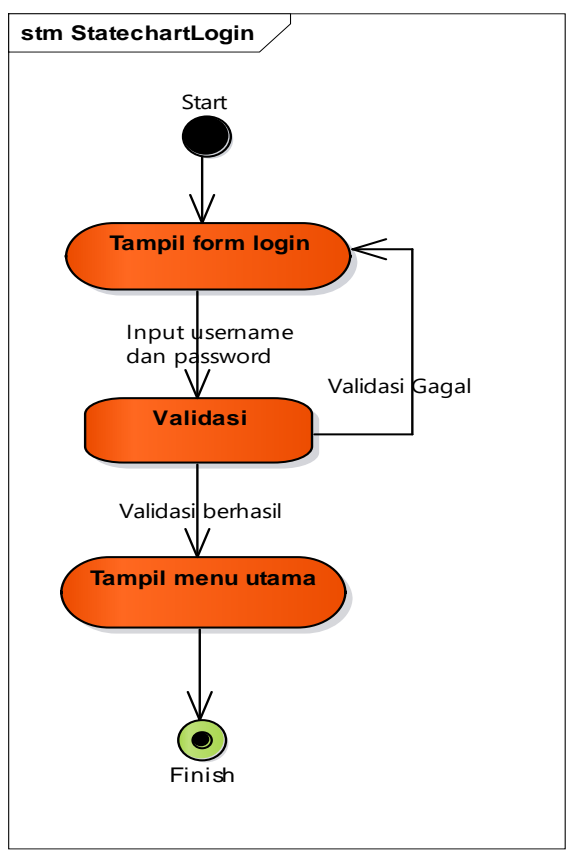

\section{Gambar 3. StateChart Diagram Login}

Deskripsi Gambar 3. Tampilan login akan muncul jika user masuk ke website terlebih dahulu dan ingin melakukan login sistem.

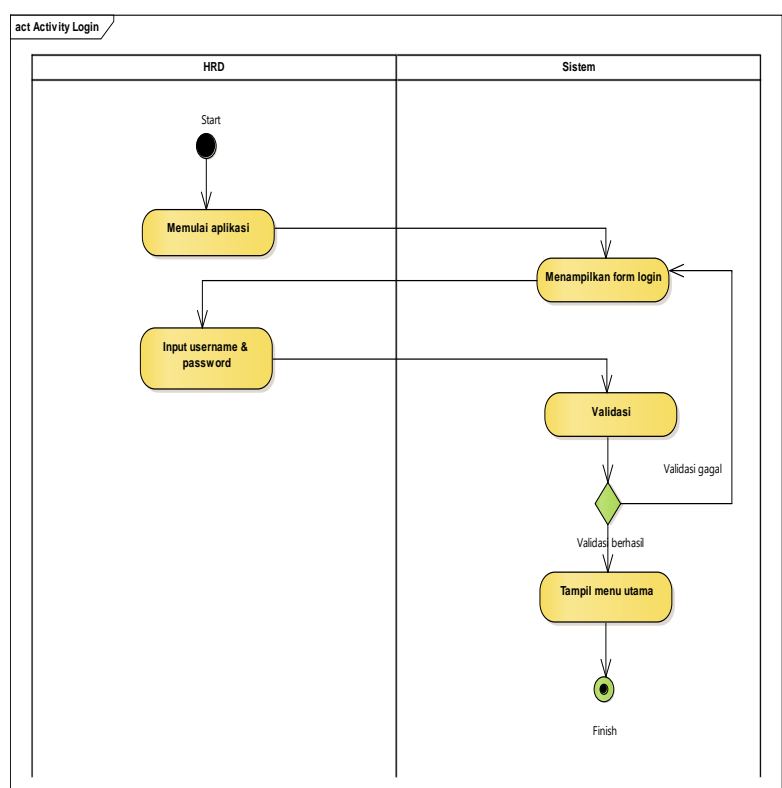

Gambar 4. Activity Diagram Login

Deskripsi Gambar 4. Sama dengan deskripsi gambar 3. 


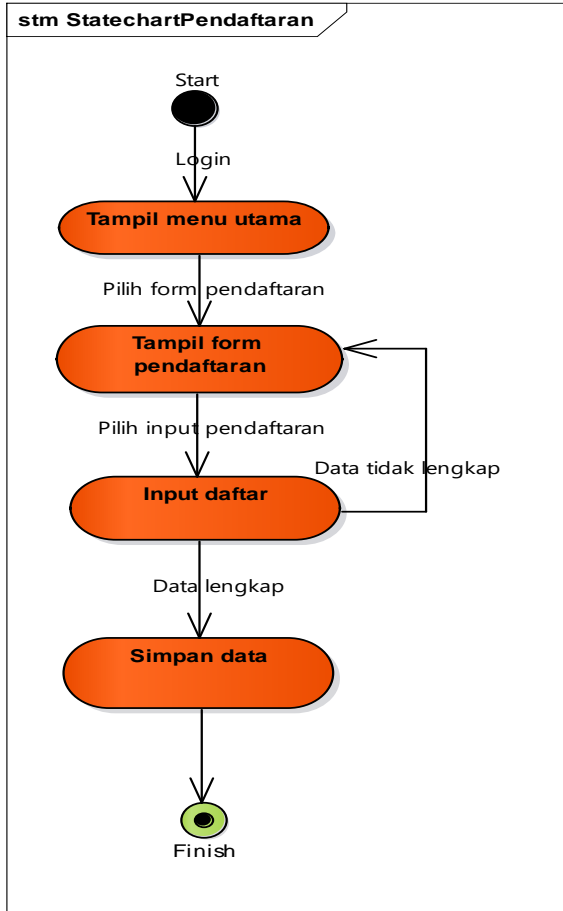

Gambar 5. StateChart Diagram Pendaftaran

Deskripsi Gambar 5. Tampilan menu pendaftar untuk calon karyawan baru akan muncul jika calon karyawan baru berhasil masuk. Dalam menu ini calon karyawan baru menginput data-data lamaran yang perlukan perusahaan

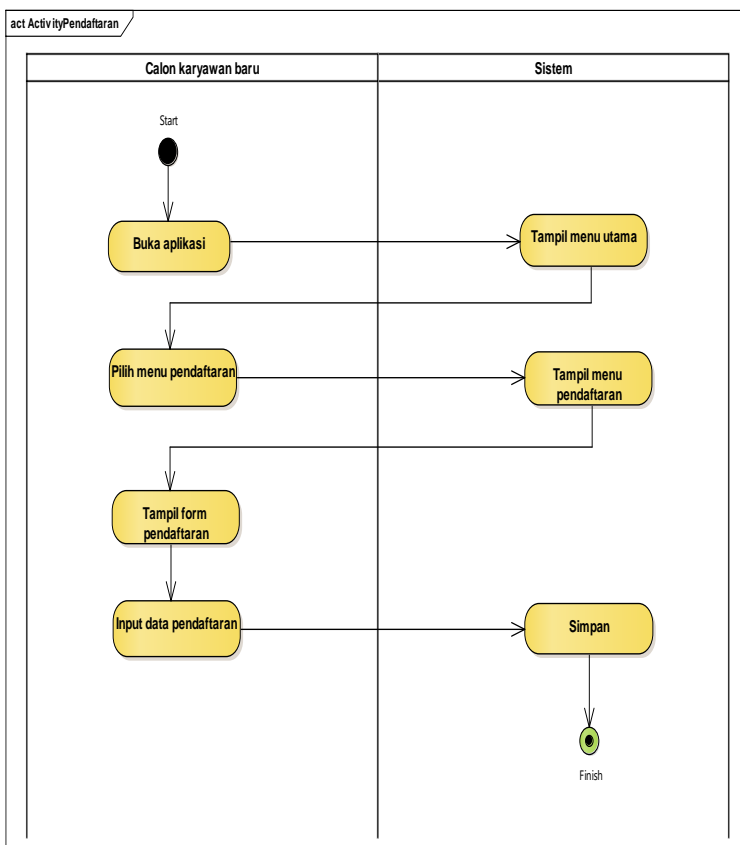

Gambar 6. Activity Diagram Pendaftaran Deskripsi Gambar 6. Sama dengan deskripsi gambar 5.

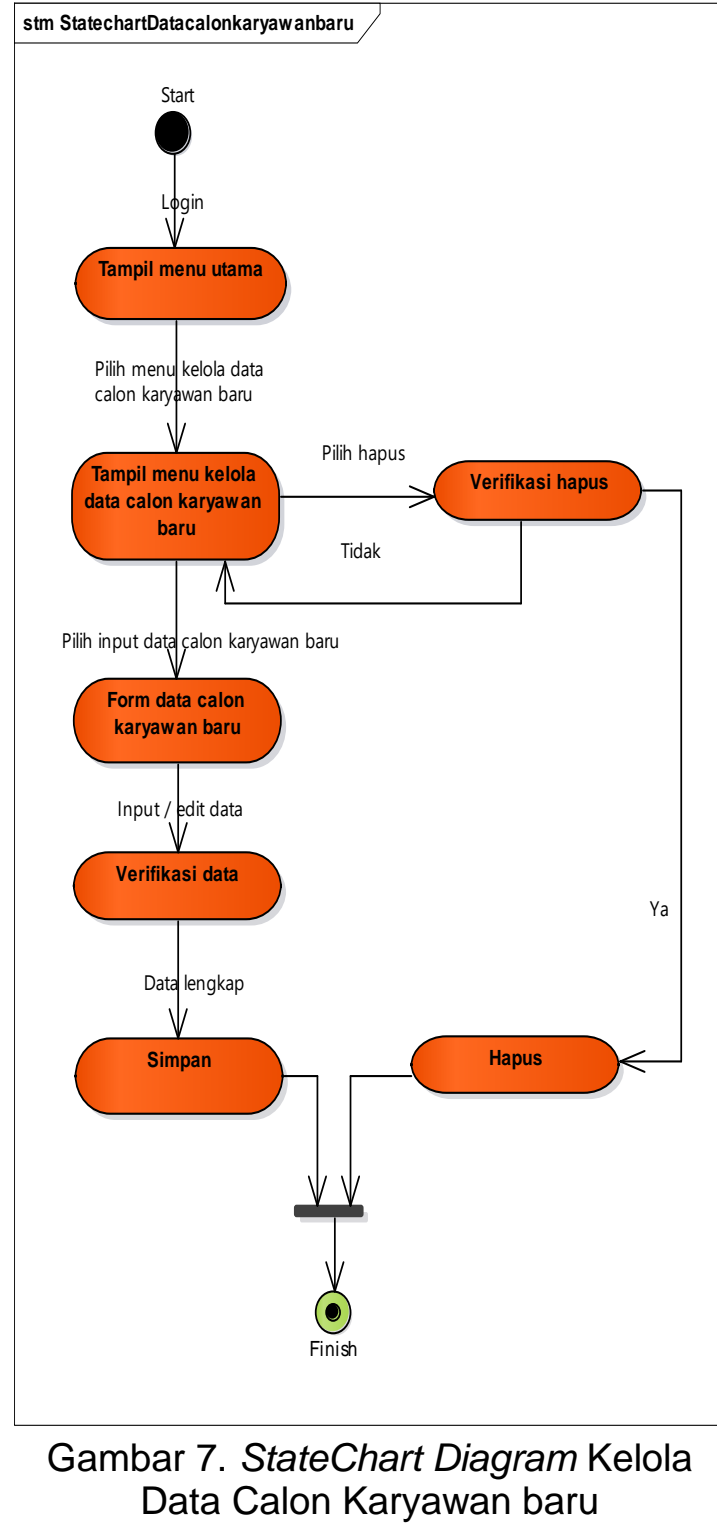

Deskripsi Gambar 7. Tampilan ini akan menampilkan Data Calon karyawan baru dan di kelola oleh HRD, dimana pada menu ini HRD bisa menambah, mengedit, menginput, dan menghapus data calon karyawan baru. 


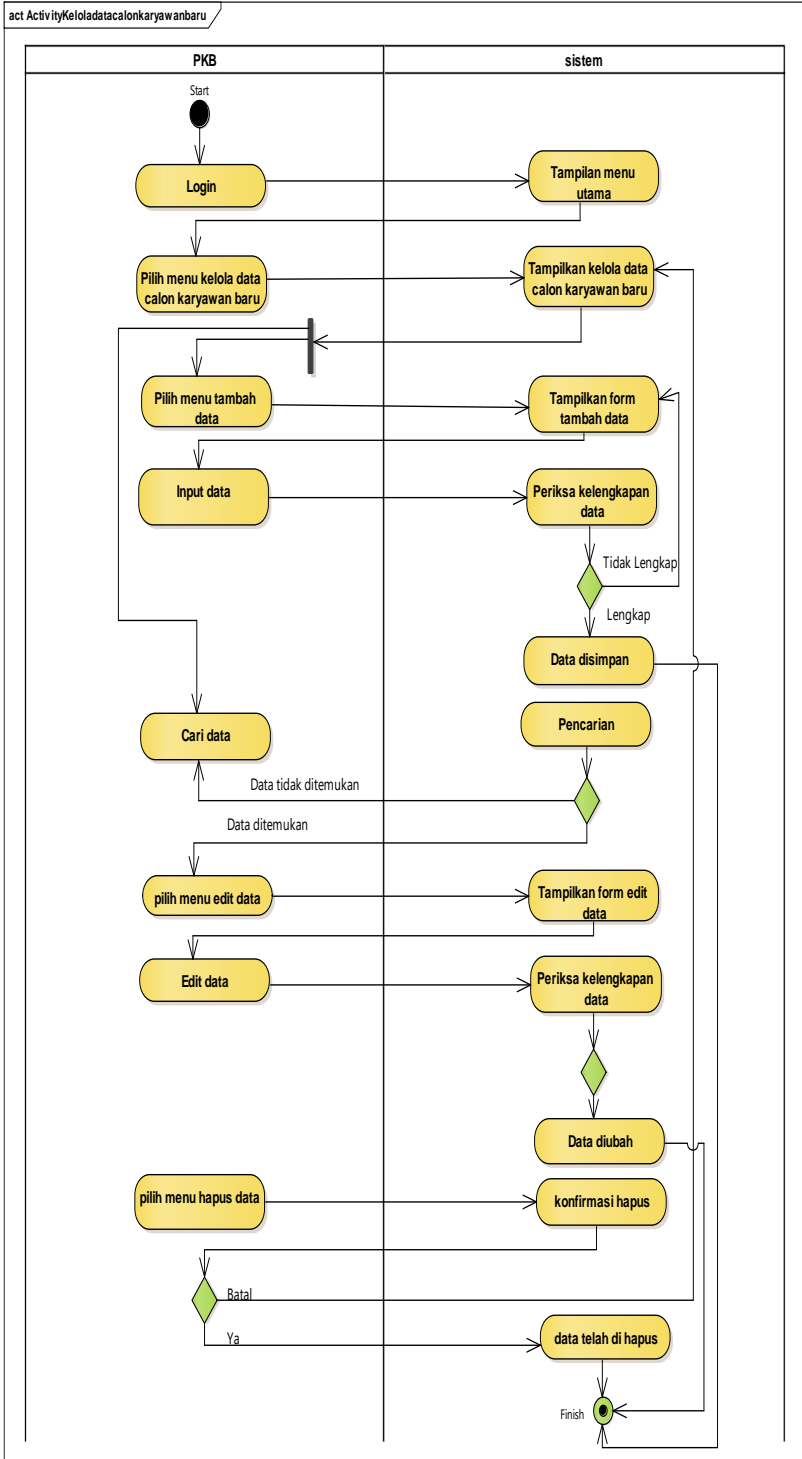

Gambar 8. Activity Diagram Pendaftaran

Deskripsi Gambar 8. Sama dengan deskripsi gambar 7. Pada Statechart Diagram Pendaftaran

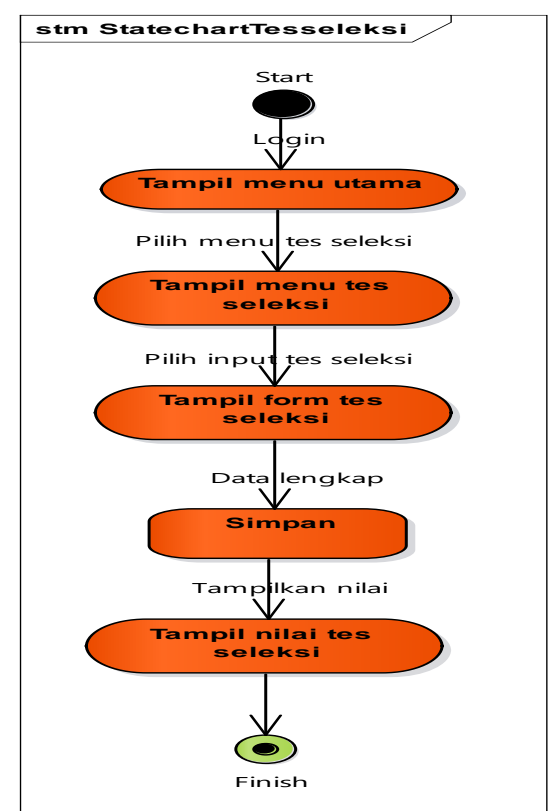

Gambar 9. StateChart Diagram Tes Seleksi

Deskripsi Gambar 9. Tampilan ini menampilakan soal tes seleksi untuk calon karyawan baru, jika calon karyawan baru telah selesai menjawab semua soal yang ada pada tes seleksi maka nilai akan otomasi muncul pada menu tes seleksi.

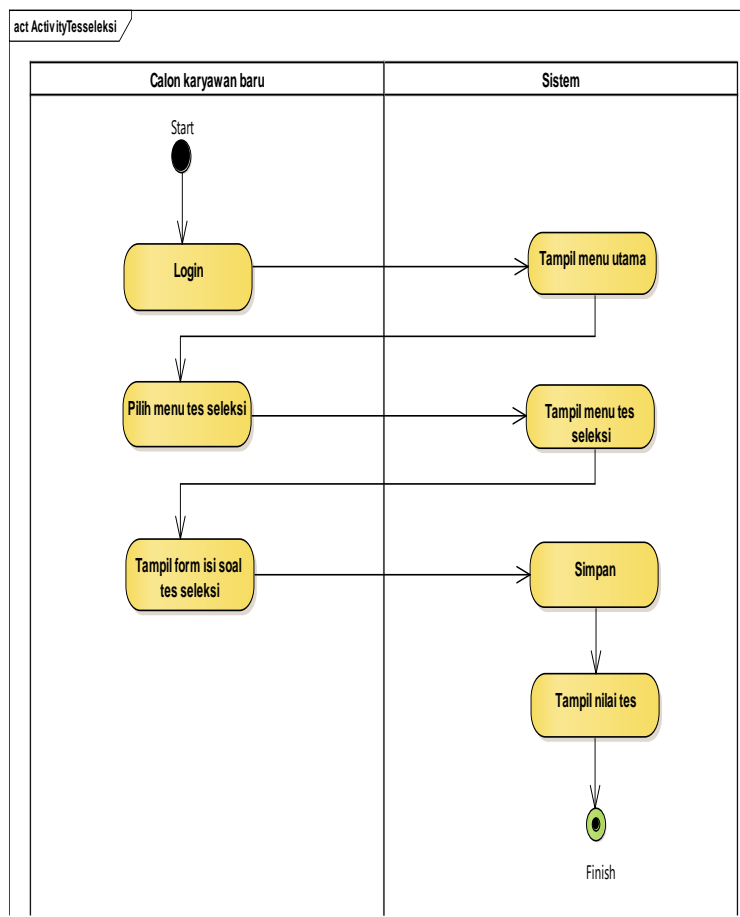

Gambar 10. Activity Diagram Tes Seleksi

Deskripsi Gambar 10. sama dengan deskripsi gambar 9. Pada Statechart Diagram tes seleksi. 


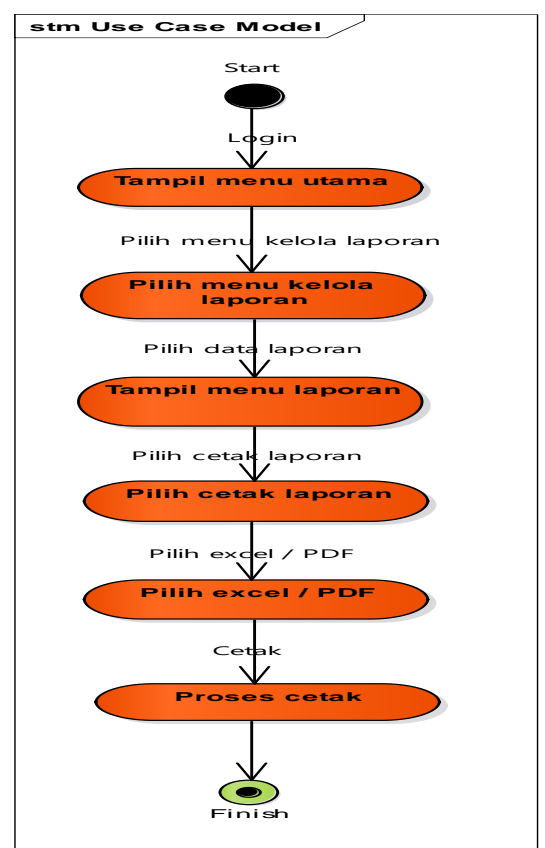

Gambar 11. StateChart Diagram Laporan

Deskripsi Gambar 11. Tampilan ini akan menampilkan laporan kelola data calon karyawan baru dan laporan tes seleksi, dan laporan bisa di cetak sesuai kebutuhan user

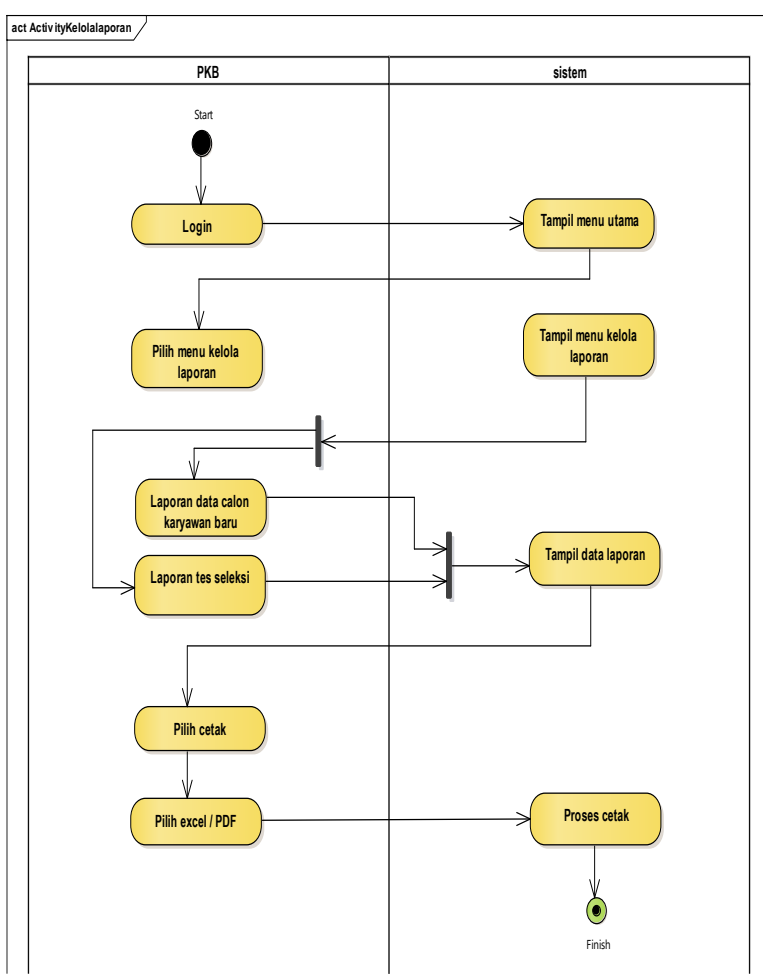

Gambar 12. Activity Diagram Laporan

Deskripsi gambar 12. Sama dengan deskripsi gambar 11. Pada Statechart Diagram Laporan

\section{Tampilan Sistem Yang Diusulkan}

Pada rancangan desain tampilan ini akan menampilkan apa yang sesuai dan statechart dan activity diagram diatas, menampilkan beberapa menu, Pendaftaran, Kelola data calon karyawan baru, Tes seleksi dan Laporan, yang berisi laporan data calon karyawan baru dan laporan tes seleksi.

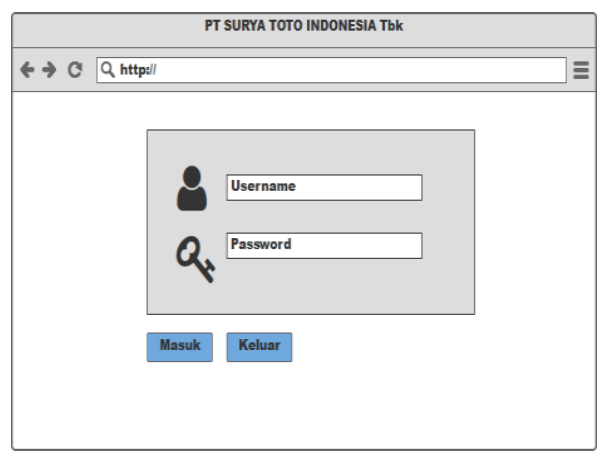

Gambar 13. Tampilan login

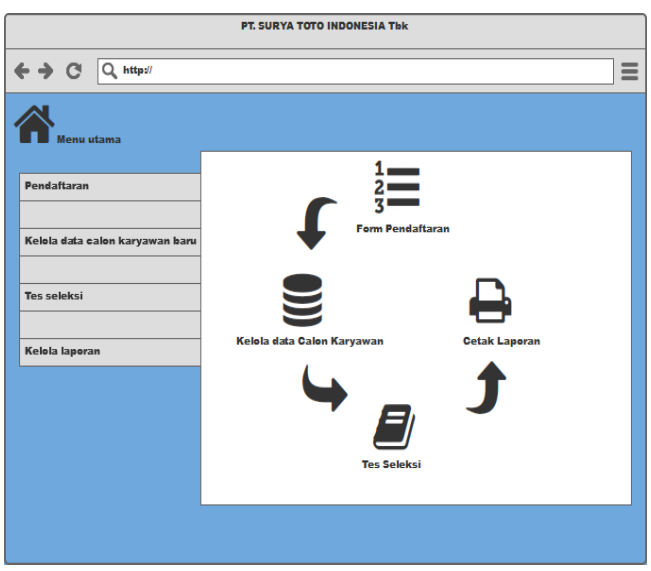

Gambar 14. Tampilan Menu utama

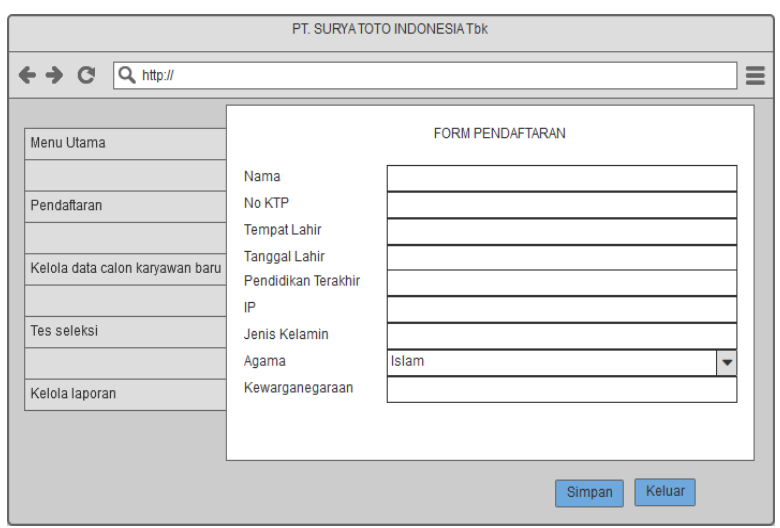


Gambar 15. Tampilan Menu Pendaftaran

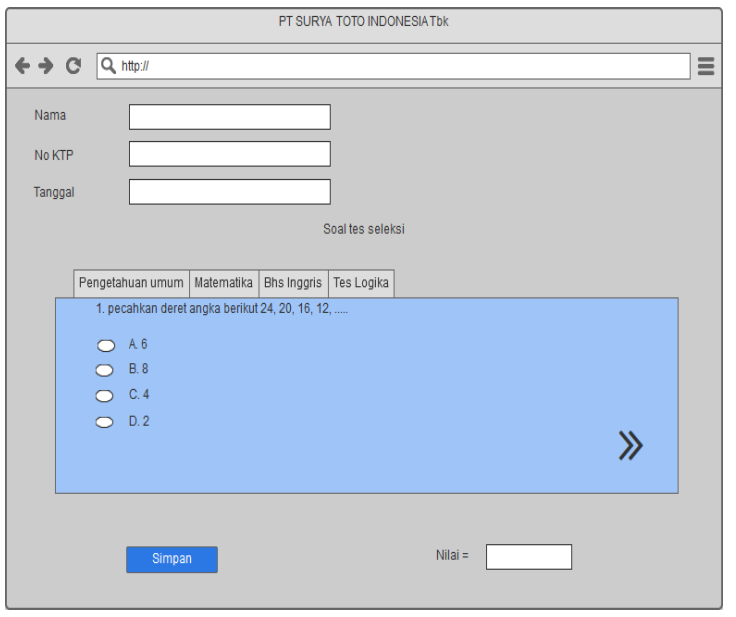

Gambar 17. Tampilan Menu Tes Seleksi

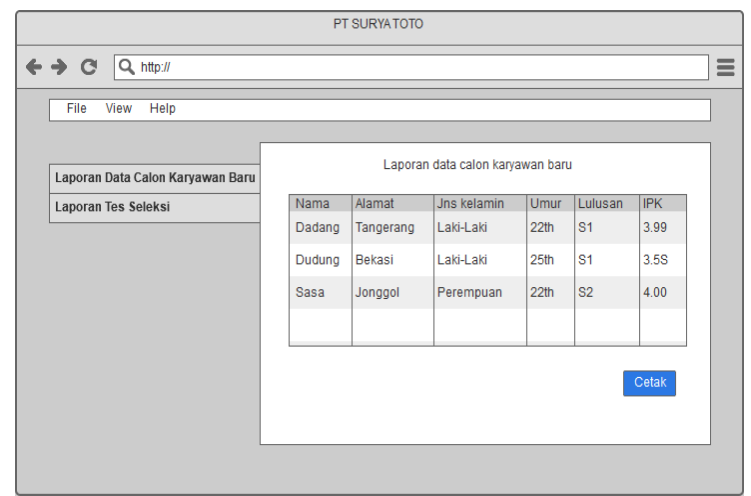

Gambar 18. Tampilan Menu Laporan

\section{PENUTUP}

Berdasarkan uraian pada pokok bahasan diatas, maka dapat disimpulkan sebagai berikut:

1. Diperlukannya sebuah sistem yang dapat membantu Penerimaan karyawan baru dalam mengelola, mendata, dan meminimalisir kesalahan dalam pembuatan laporan karyawan baru

2. Hasil analisis dan desain ini bisa digunakan sebagai masukan untuk merancang sebuah sistem informasi penerimaan karyawan.

\section{DAFTAR PUSTAKA}

[1] Whitten L. Jeffery.2004. System Analysis and Design Methods, $6^{\text {th }}$ Edition. Mc Graw Hill.

[2] Jogiyanto HM (2005). Analisis \& Desain. Penerbit Andi. Yogyakarta

[3] Rohmat Taufiq. 2013. Sistem Informsi Manajemen; Konsep Dasar, Analisis dan Metode Pengembangan. Graha Ilmu. Yogyakarta

[4] James A. O'Brien. (2005). Introduction to Information System, $12^{\text {th }}$ ed. McGraw-Hill, USA.

[5] Qodri, Z. M. L. 2014, Panduan Lengkap Human Resources Division (HRD) \& General Affair (GA), Jaminan Kesehatan Nasional (JKN), Penebar Swadaya Grup, Jakarta.

[6] Adi Nugroho. 2010. Rekayasa Perangkat Lunak Berbasis Objek dengan Metode USDP. Andi. Yogyakarta 